\title{
The Dutch disease and its neutralization: a Ricardian approach
}

\author{
LUIZ CARLOS BRESSER-PEREIRA*
}

The Dutch disease is a major market failure originated in the existence of cheap and abundant natural or human resources that keep overvalued the currency of a country for an undetermined period of time, thus turning non profitable the production of tradable goods using technology in the state-of-the-art. It is an obstacle to growth on the demand side, because it limits investment opportunities. The severity of the Dutch disease varies according to the extent of the Ricardian rents involved, i.e., according to the difference between two exchange rate equilibriums: the 'current' or market rate and the 'industrial' rate - the one that make viable efficient tradable industries. Its main symptoms, besides overvalued currency, are low rates of growth of the manufacturing industry, artificially high real wages, and unemployment. Its neutralization requires managing the exchange rate. The principal instrument for that is a sales or export tax on the commodities that give origin to the Dutch disease. In order to neutralize it policymakers face major political obstacles since it involves taxing exports and reducing wages. Finally, this papers argues that there is an extended concept of Dutch disease: besides having its origin in natural resources, it may arise from cheap labor provided that the 'wage spread' in the developing country is considerably larger than in the developed one - a condition that is usually present.

Key-words: exchange rate; Ricardian rents; economic growth.

JEL Classification: E1, F43, O11.

Economic development depends on a competitive exchange rate that stimulates exports and investments. Empirical evidence regarding this proposition is clear: all the countries that developed during the twentieth century, such as Japan, Germany, Italy and, more recently, the dynamic Asian countries, have

\footnotetext{
*Professor of economics at Fundação Getulio Vargas, São Paulo. E-mail: 1cbresser@uol.com.br. Submited: August 2006; accepted: October 2006.
} 
always had exchange rates that enabled the development of their manufacturing industry. Recent econometric studies confirmed this fact. ${ }^{1}$ On the other hand, economic theory teaches that developing countries should grow faster than rich ones, that is, they should be in a process of catching up, because those countries rely on a cheaper labor to compete internationally and because they can imitate and buy technology at a relatively low cost. This assumption of economic theory has been confirmed in practice by a number of Asian countries that have been growing at high rates for many years - which allowed, in 2005, developing countries as a whole to equal rich countries' GDP. It was also confirmed for some Latin American countries between 1930 and 1980. Yet, for most developing countries, even Latin American ones since 1980, growth rates per inhabitant are lower than those prevailing in rich countries. Probably one of the most important reasons for this outcome is the Dutch disease - that is, the chronic overvaluation of the exchange rate caused by the abundance of cheap natural and human resources compatible with a lower exchange rate than the one that would pave the way for the other tradables industries. We couldn't say for certain that this is the main obstacle to the economic growth of developing countries - and particularly of medium-income countries that are already able, on the supply side, to catch $u p$ - but we will hardly find an obstacle as strong as this one.

Dutch disease is an obstacle on the demand side with serious effects on supply. Since it implies exchange rate appreciation, the Dutch disease hinders investments even when the business enterprises fully dominate the respective technology. Conventional economics tends to consider economic growth merely in terms of supply, focusing its attention on education, on a broader improvement of human capital, on scientific and particularly on technological development, on innovation, and on investments in machines that increase the worker's productivity. Yet, as Keynes and Kalecki classically demonstrated, demand is not automatically created by supply, and therefore it may become an essential obstacle to economic growth. The huge unemployment of human resources that exists in almost all developing countries presenting unsatisfactory growth rates leaves no doubt that the main problem is often on the demand side, rather than on the supply side. Demand is formed by consumption, investments, public expenditure, and trade surplus, but the key variable are investments and exports, because they can be increased without incurring costs of reduced savings, as occurs with consumption, nor costs of fiscal imbalance, as occurs with public expenditure. Not only do they directly represent demand when there is a positive balance in commercial transactions, but, in addition, they encourage demand's main variable — investments - which operate as much on the supply side as on the demand side. ${ }^{2}$ Exports are therefore

\footnotetext{
${ }^{1}$ See, among others, Razin and Collins (1997), Fajnzylber, Loyaza, and Calderón (2004), Gala (2006), Rodrik (2007).

${ }^{2}$ Investment expenditure evidently also depends on other variables, besides increased exports, such as the interest rate and, particularly, business expectations regarding the future, but these latter shall be substantially better should the entrepreneurs rely on an exchange rate that stimulates them to export.
} 
strategic in order to solve the problem of insufficiency of demand or of unemployment.

When a country is still 'poor', that is, when it has not completed its Industrial Revolution, and does not have investment capacity, nor a class of entrepreneurs and middle-class professionals to conduct investments, the country will still be caught in the poverty trap, and the problem will probably be located mainly on the supply side. When, however, it has already gone through this stage, usually as a result of having profited from its natural resources in order to start a capitalist export activity, and became a medium-income country, the main obstacle to economic development will usually be located on the demand side: there will be a chronic shortage of opportunities for lucrative investments in sectors producing tradables, whose main cause shall be the tendency to exchange rate overvaluation that exists in developing countries. This tendency, for its part, shall usually be caused mainly by the Dutch disease.

The exchange rate is, actually, the main variable to be studied by development macroeconomics, since it plays a strategic role in economic growth. If conditions exist on the supply side - and we should not overlook them - a relatively depreciated exchange rate is necessary in order to have a constant increase in exports and, as a consequence, an opportunity for lucrative investments. This is why countries that develop fast and manage to catch up usually have a competitive exchange rate, as it was the case with Japan, the other small Asian countries, and eventually China and India. When some of them (Thailand, Korea, and Malaysia), abandoned this policy in the 1990s and accepted conventional orthodoxy's recommendation of growing with foreign savings, thus appreciating their exchange rate, the outcome was the balance-of-payment crisis - a crisis that soon made them revert to the usual macroeconomic policy for those countries: strict fiscal adjustment, low interest rates, and competitive exchange rates (Gonzales, 2007). The policy of managing the exchange rate and preventing its appreciation, thus neutralizing Dutch disease, is present in the dynamic Asian countries, not in Middle Eastern, African, and Latin American countries. ${ }^{3}$ This difference could perhaps be explained by variables such as technical competence and rejection of economic populism, but it is equally due to the fact that Asian countries have relatively scarce natural resources, and therefore they are not subject to; even when they have abundant natural resources, such as Thailand, Malaysia, they did not base their growth on their exploitation. ${ }^{4}$ We can always attribute the insufficient growth of medium-income countries to political or institutional issues, but in cases such as Brazil or Mexico, which between 1930 and 1980 have managed to catch $u p$, this argument makes no sense: there are no new institutional historical facts to justify the assertion that these countries' institutional standards have

\footnotetext{
${ }^{3}$ Latin American countries used extensively exchange rate management up to the 1980s.

${ }^{4}$ They are only subject to the 'extended' Dutch disease, derived from the existence of cheap labor, whose concept I will discuss in the end of this paper.
} 
worsened; they have rather become democracies with better institutions. There are, however, two new facts or two main reasons that explain why mediumincome countries such as those two, which grew considerably in the past, are not growing enough in the present: on the one hand, there was a substantial shrinking of public investments, and, on the other hand, since the end of 1980s those countries failed to neutralize the tendency to exchange rate overvaluation which is primarily caused by the Dutch disease.

This paper has three basic arguments. First, the Dutch disease is the main determining factor of the tendency to exchange rate overvaluation, as well as a severe market failure resulting from the existence of Ricardian rents which may debilitate the country's economy indefinitely. Second, this disease can be neutralized through the management of the exchange rate and particularly through the creation of a tax on sales that will shift its supply curve upwards. Third, the Dutch disease does not derive only from natural resources but also from cheap labor, provided that the 'wage spread', that is, the difference between workers' wages and the salaries of engineers or managers in the factories is substantially higher in the country suffering the disease than in rich countries.

\section{MARKET FAILURE}

Dutch disease is a market failure resulting from the existence of cheap and abundant natural resources used to produce commodities which are compatible with a more appreciated exchange rate than the one that would be necessary to make competitive the other tradable industries. By using cheap resources, the respective commodities cause the appreciation of the exchange rate because they can be profitable at a rate which is incompatible with the rate that other goods using the best technology available worldwide require. Resources are 'cheap' because they generate Ricardian rents for the country, or, in other words, they are cheap because their costs and corresponding prices are lower than those prevailing on the international market, which are determined by the less efficient marginal producer admitted to this market. Dutch disease, however, is not the sole factor causing the general tendency that I propose to exist in developing economies: the tendency to exchange rate overvaluation. A number of factors, some of them market factors, others arising from strategies proposed by rich countries, are behind this tendency which impairs or prevents countries' industrialization and growth: the higher profitability of investments in developing countries, which attracts foreign capital and pushes the exchange rate down; the proposal of a 'financial deepening', that is, of raising interest rates in developing countries in order to attract foreign capital; the exchange rate populism adopted by irresponsible politicians; the always present temptation of using the exchange rate appreciation to control the inflation rate; and the growth with foreign savings policy proposed by rich countries to developing ones, which implies current account deficits. The higher profitability of investments in developing countries 
is a structural condition related to the shortage of capital; exchange rate populism is the counterpart of fiscal populism: whereas in fiscal populism the state organization or apparatus spends more than it collects, incurring chronic and irresponsible public deficits, in exchange rate populism it is the Nation-state or country that spends more than it collects, incurring chronic current account deficits; ${ }^{5}$ the rise in the interest rate in the name of a 'financial deepening', the use of exchange rate anchors to control inflation, and particularly the growth with foreign savings policy are conventional orthodoxy policies repeatedly recommended to developing countries. ${ }^{6}$ All those factors are also significant and interconnected, and I have already discussed them in other papers. ${ }^{7}$

Dutch disease is a market failure that affects almost all developing countries and may permanently obstruct their industrialization, since the market converges on a long term equilibrium exchange rate that is caused by this disease. The Dutch disease is consistent, in the long run, with the 'equilibrium' of a country's foreign accounts, that is, with a balanced current account - something that does not occur with the the growth with foreign savings policy, whose threshold, in the medium term, is balance of payment crisis. In order to discuss the Dutch disease, I will first define it in a conventional way as related to the abundance of cheap natural resources; second, I will point to the circumstances that allow us to diagnose the Dutch disease; third, I will show that it is not limited to oil-producing countries, since countries such as Brazil have only reached industrialization as long as they were able to neutralize its effects, nor that the commodities' production presents a low value-added per capita. Next, I will discuss the 'extended concept of Dutch disease' which equally applies to countries such as China that, even though lacking as many natural resources or not using them as intensely in their growth process, have, however, cheap labor.

\section{CONCEPT}

Dutch disease or the curse of natural resources is the chronic overvaluation of a country's exchange rate, caused by its exploitation of abundant and cheap

\footnotetext{
${ }^{5}$ On economic populism see Bresser-Pereira, org. (1991), and Dornbusch and Edwards, orgs. (1991). The classical studies on economic populism, including fiscal and exchange rate populism, were written by Adolfo Canitrot (1975), Carlos Dias Alejandro (1982), and Jeffrey Sachs (1988) and are all reproduced in the book organized by me.

${ }^{6}$ When a country is receiving foreign savings, the current account deficit is consistent with a more appreciated exchange rate than the one that would prevail if the current account were balanced.

${ }^{7}$ I have criticized the growth with foreign savings policy, particularly in Bresser-Pereira and Nakano (2002), Bresser-Pereira (2002, 2004), Bresser-Pereira and Gala (2007). In Brazil, between 1994 and 1999, when foreign savings received by the country increased extraordinarily, as the current account deficit went from zero to nearly $4.5 \%$ of GDP whereas the investment rate remained virtually stable, the rate of substitution of foreign for domestic savings exceeded 100\% (Bresser-Pereira, 2007: 162).
} 
resources whose commercial production is consistent with an exchange rate clearly below the average exchange rate that paves the way for tradables economic sectors using state-of-the-art technology. As Corden and Neary (1982) have stressed, it is a structural phenomenon that provokes de-industrialization. Some authors (Baland and François, 2000; Sachs and Warner, 1999 and 2001; Torvik, 2002; Larsen, 2004) make a distinction between Dutch disease and the curse of natural resources: whereas Dutch disease would be a market failure, the curse of natural resources would result from corruption or rent-seeking, arising from the abundance of such resources in countries with a backward society and weak institutions. Although the problem of corruption exists in all countries and is more serious in poor countries rich in natural resources, I will not discuss this issue here and will not tell the difference between both concepts.

The Dutch disease is consistent with the intertemporal equilibrium of foreign accounts, and may, therefore, produce negative effects indefinitely. It is a market failure because the sector producing natural resource-intensive goods generates a negative externality ${ }^{8}$ on the economy's other sectors, preventing those sectors from developing despite their use of state-of-the-art technology. It is a market failure that implies the existence of a difference between the exchange rate that balances the current account (which is the market rate) and the exchange rate that enables efficient and technologically sophisticated economic sectors (which is the rate that economics predicts that efficient industries will be viable in competitive markets). Only when the Dutch disease is neutralized will the market be able to play its role in effectively allocating resources and in encouraging investment and innovation. The Dutch disease is an old problem, but it received this name because it was identified only in the 1960s in the Netherlands, when its economists found that the discovery of natural gas and its export were appreciating the exchange rate and threatened to destroy its whole manufacturing industry. It was only in the 80's that the first academic studies on the subject appeared (Corden and Neary, 1982; Corden, 1984). Even today the literature on the subject is scarce and insufficient.

The Dutch disease leads to an exchange rate that prevents the production of tradables that do not use the resources that give rise to it. For this occur, a sector that uses a country's natural resources must be substantially more productive than this same sector in other countries, so that it gives rise to Ricardian rents that is, its market price should be defined on the international market by the less efficient producer on the margin -, or whose price derives from monopoly power. In these terms, Dutch disease is the market failure that derives from Ricardian rents associated to the production and export of a limited number of goods

\footnotetext{
${ }^{8}$ The idea that the Dutch disease implies a negative externality was suggested to me by José Luiz Oreiro. It is thus easier to understand why it constitutes a market failure - a situation where prices do not reflect the (marginal) social cost of production of goods.
} 
produced with those natural resources. In their model, Corden and Neary (1982) supposed an economy with three sectors, two of them related to tradables (the 'booming' sector or natural resources sector, and the 'lagging' sector or the manufacturing industry sector) and a third sector of non-tradables. Sachs and Warner (2001), summarizing the literature on the Dutch disease, explain it by a wealth shock in the natural resources sector which creates an excess demand in the non-tradables sector, implying a change in relative prices. The appreciated exchange rate is defined by that change in relative prices by favouring nontradables. In the model I present here those three sectors are present, but the emphasis is placed directly on the exchange rate, and the change in relative prices that causes its appreciation is related to the Ricardian nature of the rents occurring in the sector that makes use of cheap resources - not only natural resources but also, as we shall see, labor itself.

Whereas, in Ricardo's model, Ricardian rents benefit only the owners of the most productive lands, in the case of Dutch disease they also benefit, in the short run, the country's consumers that buy relatively cheaper tradables; whereas, in the classical model, the tendency of the economy is towards stagnation, in the case of Dutch disease there will be quasi-stagnation of the country as a whole. Unlike Ricardo's model, however, the overvaluation caused by Ricardian rents transformed in Dutch disease can be neutralized. It must be stressed that, in the model I am presenting, I refer to the country's Ricardian rents, and there is no difference in productivity among local producers, but only a difference in the country's productivity in relation to the international price (that is, in the local producers' average as compared to other countries). If there is a difference in productivity, there will also be Ricardian rents among the producers, as long as the exchange rate will tend to converge on the one that favours the most inefficient local producer.

When Dutch disease exists, even the goods produced with state-of-the-art technology are not viable economically in a competitive market. If, all the other factors of competitiveness being equal, an advanced technology company sets up in a country affected by this disease, it will only be viable if its productivity is higher than the productivity achieved by the other competing countries, at the same or at a higher degree than the appreciation caused by the disease. This fact leads to the conclusion that in countries suffering from Dutch disease there are two equilibrium exchange rates: the 'current' equilibrium exchange rate - the one that balances intertemporally a country's current account and that is therefore also the market rate, the rate on which the market shall converge; and the 'industrial' equilibrium exchange rate - the one that enables the production of tradables in the country without the need of duties and subsidies (we presume here that the other external determinants of the companies' productivity are equal). Or, in other words, it is the exchange rate that, on average, allows companies using state-of-the-art technology to be profitable or competitive. In this paper, those two rates are always conceived in nominal terms: there is no need to talk about a real exchange rate because the important thing is just the 
difference or the relationship between the two equilibrium rates. Yet, we will have to distinguish the nominal exchange rate from the 'effective-effective' exchange rate, this one being understood not only as the result of using a currency basket instead of just one hard or reserve currency to calculate it (which would have just one adjective 'effective'), but also as the average exchange rate that results from taking into account the import duties and the export subsidies to which the goods are subject.

If we name $\varepsilon_{\mathrm{c}}$ the current equilibrium exchange rate, and $\varepsilon_{\mathrm{i}}$ the industrial equilibrium exchange rate, in a country without Dutch disease, the two rates will be identical:

$$
\varepsilon_{\mathrm{c}}=\varepsilon_{\mathrm{i}}
$$

whereas in a country with Dutch disease the current equilibrium exchange rate will be more appreciated than the industrial equilibrium exchange rate. If we consider that we measure the exchange rate as the price of the local currency as compared to the reserve currency, the more it is competitive, the higher will be the rate, the more it is appreciated, the lower will be the exchange rate.' Accordingly, in the presence of the Dutch disease, the current equilibrium exchange rate will be lower than the industrial equilibrium exchange rate:

$$
\varepsilon_{\mathrm{c}<} \varepsilon_{\mathrm{i}}
$$

The current equilibrium exchange rate in the country affected by the Dutch disease is determined by the marginal cost in domestic currency of the good that gives rise to it - marginal cost is here understood as the cost of the less efficient producers that manage to export. This cost is equal to the price in domestic currency that all producers, including the marginal or less effective producer that manages to export, accept in order to be able to export. When the Dutch disease occurs, this price is substantially lower than the 'necessary price' - i.e., the price that makes economically profitable to produce other tradables using technology in the state-of-the-art. It is, therefore, a lower price than the one that would be necessary for the current equilibrium exchange rate to be identical to the industrial equilibrium exchange rate. As long as this domestic marginal cost is lower than the above defined 'necessary price', and as long as the participation of that commodity in the country's export portfolio is relevant, the market's exchange rate (which is also the current equilibrium exchange rate) converges on a level consistent with the profitability of that commodity, and not on a level compatible with the competitiveness of any industrial sector using state-of-the-art technology. The lower the marginal cost and thus the market price of the exported good as compared to the necessary price, the higher the Ricardian rent, and the more appreciated the country's currency. Since the Ricardian rents obtained are different

\footnotetext{
${ }^{9}$ We are here defining the exchange rate as the price in national currency of the basket of currencies.
} 
from country to country depending on the productivity provided by their natural resources, the Dutch disease affects the countries to different degrees or intensities. The higher the difference in productivity of every product that gives rise to the disease as compared to its necessary price, the higher will be the currency's overvaluation, and the more serious the Dutch disease.

The factors determining the necessary price of that commodity (always in domestic currency) are, on the one hand, the average productivity of the tradables using state-of-the-art technology but not benefiting from natural resources, which defines the industrial equilibrium exchange rate, and, on the other hand, the variations in the international price of such goods. If there is a Ricardian rent (resulting from differences in productivity and from the existence of an international market price corresponding to the less efficient producer) the necessary price shall be higher than the market price, or, in other words, the current equilibrium exchange rate shall be more appreciated than the industrial equilibrium exchange rate. The Ricardian rents earned by each country, by making the market price lower than the necessary price, determine the intensity or the severity of its Dutch disease. We must emphasize that the difference between the real and the necessary price should be large and constant enough so that we can talk about a Dutch disease. Otherwise, it would be present whenever there was a comparative advantage, and therefore whenever there was trade.

Defined as above, the market price, $\mathrm{p}_{\mathrm{m}}$, of the commodity shall be proportional to the current equilibrium exchange rate, whereas the necessary price, $\mathrm{p}_{\mathrm{n}}$, shall be proportional to the industrial equilibrium exchange rate.

$$
\begin{aligned}
& \mathrm{p}_{\mathrm{m}::} \varepsilon_{\mathrm{c}} \\
& \mathrm{p}_{\mathrm{n}::} \varepsilon_{\mathrm{i}}
\end{aligned}
$$

Given a marginal cost or market price pm in domestic currency, and an international price, $p_{x}$, the current equilibrium exchange rate, $\varepsilon_{\mathrm{C}}$, shall be identical to $\mathrm{pm} / \mathrm{px}$.

$$
\varepsilon_{\mathrm{c}}=\mathrm{pm} / \mathrm{px}
$$

The intensity of the Dutch disease can be measured by the ratio between this country's current equilibrium exchange rate and its industrial equilibrium exchange rate, as well as by the ratio between the market price and the necessary price. Let's take the second one. In this case, the intensity of the Dutch disease, dh, shall be:

$$
\mathrm{dh}=[1-(\mathrm{pm} / \mathrm{pn})] * 100
$$

The intensity of the Dutch disease, therefore, is always

\section{$0 \mathrm{f}$ dh $\mathrm{f} 1$}

Let's presume, for instance, three countries: the country Z1, which exploits oil at a marginal cost or at a market price corresponding to $20 \%$ of the price the product should have if the exchange rate corresponded to the industrial equilibrium 
exchange rate, that is, the necessary price; the country Z2, which still exploits oil, but whose marginal cost as compared to the necessary price is $50 \%$; and the country Z3, which exports a combination of products such as iron, oil, ethanol, wood, orange juice and soybean at a cost equivalent to $80 \%$ of the average necessary price. In these three cases, the intensity of the Dutch disease shall be, respectively, 80,50 and $20 \%$.

In the country Z1 as much in the Z2, the Dutch disease's intensity is so high that there will be no room for the production of any other internationally tradable good. Yet the country Z3 can keep and even export if it has very efficient enterprises.

However, the intensity of the Dutch disease, besides being different from country to country, will be different inside each country, depending on the international price of the good or goods that give rise to it. The higher the international prices of a commodity, the more appreciated the current equilibrium exchange rate and the more serious the Dutch disease. For the goods exported by the country Z3, there may be a huge increase in international prices due, for instance, to an increase in the demand of those goods. In this case, let's presume that the current equilibrium exchange rate in that country was 2.20 and falls to 1.90 units of local currency per reserve currency, that is, that it represents no longer $80 \%$ but $69.1 \%$ of the industrial equilibrium exchange rate. In this case, the Dutch disease gets worse, going from $20 \%$ to $30.9 \%$.

Briefly, presuming that for all countries the industrial equilibrium exchange rate is equal to 100 , the lower the current equilibrium exchange rate is as compared to this level, the more serious shall be the Dutch disease. This severity or intensity will depend on Ricardian rents, which, in turn, will depend on the difference in productivity and on the variations in the goods' international price.

\section{NEUTRALIZATION}

If we take into account not the possession but the exploitation of natural resources, the countries that exploited more their natural resources commercially were those that developed less. Since World War II Asian non oil-exporting countries grew more than Latin American non oil-exporting countries, and these latter grew more than all the oil-exporting developing countries. Mineral rich African countries practically did not grow. Many factors have certainly contributed to this outcome, but given the weight of the Dutch disease, we may generalize asserting that the smaller will be the probability that countries could neutralize it successfully. Evidently, it was easier to neutralize the Dutch disease in Asia than in Latin America and Africa, and easier in non oil-producing countries than in oil-producing ones. 
The neutralization of the Dutch disease always involves managing the exchange rate - something that is not incompatible with a floating exchange rate. In terms of exchange regime, the reasonably consensual option nowadays is that of a floating but managed exchange rate. The alternative of a fixed exchange rate is now discarded, but this doesn't mean that the exchange rate should or could be left at the market's whim, nor that the widespread practice of managing it should be called 'dirty exchange rate'. The pragmatic solution is to reject the 'fix or float' opposition, and to manage the exchange rate. To manage it in order to prevent its appreciation, whether by keeping a domestically low level of interest rate, or by acquiring international reserves, or by levying taxes on the goods that cause the Dutch disease, or, during temporary periods, by imposing controls to capital inflows. The first two measures are adopted by virtually all countries, even though they do not admit that they are managing their exchange rate. The third one is only necessary for countries that face the Dutch disease. The fourth one is a measure to be adopted only in situations of excessive pressure for appreciation of the local currency. Conventional economics naturally rejects the idea of managing the exchange rate. The countries that have international reserve currency are those that are less able to manage their exchange rate because this would reduce the confidence of financial agents. Probably for that reason conventional economics attaches much less significance to the exchange rate than it actually has, and denies the possibility of managing the exchange rate in the medium term despite all historical evidence.

The neutralization of the Dutch disease can be completely achieved by two measures. First, a tax or contribution on the sale of the goods that give rise to it will do the job. ${ }^{10}$ This tax should correspond to the percent difference between the current equilibrium exchange rate provided by its lower cost and the industrial equilibrium exchange rate that opens the way for tradable sectors in state-of-theart technology. Second, the neutralization is completed by the creation of an international fund with the resources derived from this tax; the fund will prevent that the inflow of the tax resources re-appreciates the exchange rate. This was essentially what Norway did after it discovered and began to export oil from the North Sea. Great Britain, that discovered oil at the same time, did not neutralize the Dutch disease and its economy suffered the consequences (Chatterji and Price, 1988). Chile also neutralizes adequately the Dutch disease by heavily taxing copper exports, but this is a partial neutralization, since the revenue from the tax is not directed to the establishment of an international fund. Every oil-producing country taxes its exports, but usually at a level that is unable to neutralize the Dutch disease. Usui (1998) studied the cases of Indonesia and Mexico and showed that whereas Indonesia adequately neutralized the Dutch disease, Mexico did

\footnotetext{
${ }^{10}$ The tax cannot be imposed only on exports because this would imply an artificial deviation of production to the domestic market.
} 
not. Higher fiscal discipline in Indonesia made it possible for this country to buy and sterilize reserves in order to prevent an exchange rate appreciation, paying a very low interest rate for such acquisitions.

The direct way of neutralizing the Dutch disease is through a tax on sales and exports. The desired effect of the tax is microeconomic: it shifts upwards the supply curve of the good in order to bring up its marginal cost approximately to the level of the other goods. I say approximately because there is no simple way of estimating the necessary rate of this tax. The tax rate, $\mathrm{m}$, must be enough to cancel or to zero the Dutch disease. Therefore, it must be equal to the intensity of the Dutch disease divided by the ratio between the current equilibrium exchange rate and the industrial equilibrium exchange rate of this product:

$$
\mathrm{m}=\mathrm{dh} /\left[\mathrm{e}_{\mathrm{c}} / \mathrm{e}_{\mathrm{i}}\right]
$$

For the country $\mathrm{Z} 3$, for instance, at the initial situation in which $\mathrm{e}_{\mathrm{c}} / \mathrm{e}_{\mathrm{i}}$ is equal to 0.8 , the tax rate must be $25 \%$.

The tax or contribution on sales should, therefore, be different for each product according to the intensity of the Dutch disease it causes. Thus, to determine the $\operatorname{tax} \mathrm{q}_{\mathrm{i}}$ for each product $\mathrm{i}$, we should use the ratio between the market price and the necessary price of each good, which we have already seen that are proportional to the two exchange rates. We have, therefore,

$$
\mathrm{q}_{\mathrm{i}}=\mathrm{dh} /\left[\mathrm{p}_{\mathrm{mi}} / \mathrm{p}_{\mathrm{ni}}\right]
$$

Besides, it should vary in time, because the intensity of the Dutch disease will increase or decrease depending on the international price of the good. The law that creates the tax should leave the task of defining this rate and varying it in time to the economic authorities that manage the tax.

According to the above defined terms, neutralizing the Dutch disease appears to be a simple task, but actually it can be very difficult. First, because the government will have to face the resistance of exporters of the commodities giving rise to the Dutch disease. This resistance is usually high although it is irrational, because the purpose of the tax is not to reduce the sector's profitability, but to maintain it and eventually make it even more stable, as long as the resources from the tax, besides constituting an international fund so that their inflow to the country does not put pressure on the exchange rate, should also be used as an exchange rate stabilization fund. In order to maintain profitability, the tax can only be 'marginal': it shall only be applied on gains resulting from the depreciation achieved by the tax, or, preferably, by temporary measures of inflow control. When the tax is created and the product's supply curve in local currency shifts upwards, this movement causes depreciation, so that the amount the exporter pays as taxes is received back as an increase in his revenue in local currency. Assuming that this depreciation is obtained mainly by a transitory imposition of inflow controls, the export tax will later enable and ensure that the exchange rate stabilizes at the industrial equilibrium level. Of course, there is a problem here of transition costs from a position to another, which must be taken into account 
and offset by the government. On the other hand, if the country has a significant weight (market share) in the international supply of the good, the tax can also have the effect of increasing its international price. This effect shall probably be small but cannot be neglected, because the increase in international prices due to the tax worsens the Dutch disease that the tax aims to neutralize.

Secondly, the tax faces a macroeconomic difficulty since it implies a transitory rise in inflation. However, provided that there won't be any formal or informal indexation of economy, the prices will subsequently stabilize. A cooling down of the economy during transition may reduce this transitory increase in inflation, but will not cancel it.

A third and fundamental problem is the decrease in wages caused by the depreciation of the local currency. Effective depreciation minus inflation is by definition a change in the relative prices in favor of tradables, whose relative price increases as compared to the price of non-tradables. Whereas currency is overvalued because of the Dutch disease, wages are artificially high because people is directly benefiting from the Ricardian rent. ${ }^{11}$ The creation of a tax that neutralizes the Dutch disease by appreciating the domestic currency implies, therefore, the decrease in the actual returns on labor and on real property rents, even after corrected for inflation. It also implies a relative decrease in the revenues of the producers of non-tradables, such as hotel industry, building industry, etc., that lose participation in the national income. In other words, while the Dutch disease was operating, the country's Ricardian rents were not being captured only by commodity producers, but were benefiting all local consumers, who were buying tradables at lower prices. When the tax is created, the Ricardian rents remain in the country, but they now become State revenue. We understand, therefore, that it is not easy to create this tax, from a political point of view.

In the fourth place, not many countries have as Norway political conditions for allocating the whole revenue from the tax to set up funds abroad, as well a stabilization fund of exported commodities. In less developed countries, the tax is generally used for fiscal purposes, since its existence reduces the government's ability to finance its expenses with the direct and indirect taxes used by all countries. This is the case of Chile, for instance. However, although we should not confuse this fund with reserves obtained by countries with domestic indebtedness, the formation of those reserves is an indication that, after all, the creation of neutralizing funds is not as difficult as we could imagine.

It is understandable, therefore, that countries severely affected by the Dutch disease, such as Saudi Arabia or Venezuela, have difficulty neutralizing it. All the

\footnotetext{
${ }^{11}$ One can naturally argue that, by keeping the exchange rate depreciated, the country is internally producing sophisticated goods that could be imported at a lower price, hence the consumers surplus, but this is not the case. The country is producing all the goods with state-of-the-art technology, and there is no protection. The wage earners or consumers, however, lose in the short run in terms of well-being, because this is the condition for neutralizing the Dutch disease.
} 
oil-exporting countries encumber oil export with taxes, but usually the tax has merely fiscal purposes and the tax rate is unable to compensate for the overvaluation caused by the disease. The state lacks power to levy a higher tax, whether because even the exporting companies of the goods resist, or because the population as a whole resists the increase in the prices of all tradables, both imported and produced locally, caused by the depreciation. Besides, the state ends up by using the resources to finance its current expenses rather than to set up the financial fund abroad, on account of the economic agents' resistance to pay taxes.

Once neutralized the Dutch disease by the tax and the creation of the international fund, the two equilibrium exchange rates become reasonably identical. The country will be living its everyday life as any other country, and will be using its Ricardian rents to set up a fund abroad that will yield future benefits.

\section{SYMPTOMS}

We may identify two situations of Dutch disease: the one that have always existed and prevented industrialization, as is the case with oil-producing countries; and the situation of the country that, for a while, succeeded in neutralizing the disease and therefore developed, but, from a certain time on, in the name of a radical liberalism, eliminated the mechanisms of neutralization and began to grow at very low rates, as is the case with Latin American countries that underwent liberalizing reforms without replacing the old system of duties and subsidies by a more rational system of taxes on sales of commodities giving rise to the disease.

The most important symptoms of Dutch disease are exchange rate overvaluation, low growth of the manufacturing sector, fast increase in the services sector, high average wages, and unemployment (Oomes and Kalcheva, 2007). As it is a market failure on the demand side, limiting the existence of investment opportunities in the manufacturing industry, it only exists when there is unemployment of a country's human resources, or, in other words, when a country has technical and administrative conditions for investing in the production of goods with more sophisticated technology and higher wages, but the prevailing exchange rate prevents those investments from being made. Notwithstanding unemployment, Dutch disease implies artificially high wages. However, wages may also be low, because the workforce is abundant and disorganized in the country. The distribution of Ricardian rents involved in the Dutch disease will vary from country to country depending, therefore, on the pressure or rent-seeking ability of the various groups.

Countries affected by the Dutch disease either have been exporting a natural resource for a long time but never achieved industrialization, or achieved industrialization for some time but later engaged in a process of premature deindustrialization. In the first case, the country has never neutralized the Dutch 
disease, which takes on a relatively permanent quality. Its obvious symptom is the fact that this country does not produce other tradables but those benefited by the Ricardian rents of the Dutch disease. This is certainly the case of the country $\mathrm{Z} 1$ and probably of Z2. If the country already has a significant production and export of natural resources which allowed it to accumulate capital and to have a significant entrepreneurial class, but doesn't have a tradable industry, this is a sign that it is affected by severe Dutch disease. Saudi Arabia or Venezuela are good examples of this case.

In the second case, the country has abundant natural resources and exports them but even so, it achieved industrialization, and, therefore, neutralized the Dutch disease - usually making use of import duties and export subsidies. However, under international pressure, accused of 'protectionism', this country abandoned neutralization in the name of trade liberalization despite the fact that there was, actually, no protectionism in those duties but mere neutralization of a market failure. As a consequence of liberalization, the effective-effective exchange rate actually appreciates, if we take into account, when measuring the exchange rate before liberalization, the duties and subsidies that made it actually more depreciated. The appreciation is not immediately perceived, since it is disguised by the fact that part of the appreciation results from the elimination of duties and subsidies. Yet, the country's manufacturing industry soon begins to suffer the effects of the appreciation, and premature de-industrialization is under way. If the disease is not very intense, as in the case of country Z3, the symptoms of deindustrialization shall not be clear, although they would be reflected in the decreased participation of the manufacturing industry in the domestic product and in net exports (in terms of value added).

If the country abandons neutralization with or without an increase in international prices, it will only be able to maintain manufacturing sectors and tradable services with a zero import duty if the severity of the Dutch disease is small enough to be compensated by the country's possible higher productivity regarding its international competitors. Generally, however, the now overvalued exchange rate will gradually compromise the tradable sectors, one by one. Faced with the fact that their foreign sales are no longer lucrative, and that the import of competing goods is growing, enterprises will first redouble their efforts to increase productivity; then, they will reduce or suspend exports, or will increase the participation of imported components in their production, in order to reduce costs; ultimately, along this process, they will become mere importers and manufacturers of the good they re-export or sell on the domestic market. In other words, the country's manufacturing industry gradually becomes a "maquiladora" industry [in-bond industry]. De-industrialization is under way. The sales of manufacturing companies and even their exports may continue to present high values, but their value added will decrease, as well as their value added per capita, as we shall see later, because the components with higher technological content will be increasingly imported. 
At that moment, in view of the diagnosis that de-industrialization is taking place and that its cause is the Dutch disease, conventional economists and people associated to short-term interests in maintaining the system refuse to accept this diagnosis - and this predictable refuse constitutes another symptom of the Dutch disease. They begin then to develop empirical demonstrations to deny the fact. More radical economists will declare that even if de-industrialization is taking place, it does not prevent economic growth. Yet, not only the data but also the very logic of appreciation without a decrease in the trade balance surplus indicate that the Dutch disease is present and effective.

Another symptom of Dutch disease and of premature de-industrialization, besides the decreased participation of manufacturing industry in the product, the increase in the imported component in production, and the relative decrease in exports of manufactured goods measured in terms of value added, is the gradual decrease in the export of high value-added goods. As in the participation of exports of manufactured goods in general, the participation of manufactured goods with high technological intensity in imports is misleading, because the gross exports of companies in the process of transformation into "maquilas" remain high; what decreases is their participation in terms of value added, whose data are not always available. The reason why goods with high technological content are more affected by the Dutch disease, however, will only become clear after we present the concept of extended Dutch disease.

Even though it has the same outcome, we must, however, not to confuse this process of transformation of the country's manufacturing industry into a "maquiladora" industry [in-bond industry] as a consequence of the Dutch disease with a more general process, which is the division of tasks at international level. This growing division of production at international level is a consequence of globalization and has received several denominations: 'offshoring', when we think of a multinational company producing components abroad (Blinder, 2006), 'trade in tasks' (Grossmann and Rossi-Hansberg, 2006), or 'unbundling' (Baldwin, 2006: 1), when we want to stress the division of tasks. These two latter names clearly state that the division of labor at international level is not essentially a division between production sectors or between goods and services, but between workers. Or, as states Baldwin, for whom globalization is a second historical unbundling, "this means that international competition - that used to be primarily between firms and sectors in different nations - now occurs between individual workers performing similar tasks in different nations". Through this process, tasks with higher value-added per capita and demanding more skilled labor, formed mainly by managers and communicators, are performed in rich countries, which have plenty of this kind of labor, whereas standardized or codified tasks are transferred to low-wage workers in developing countries. This process of division of tasks that gives birth to "maquiladora companies", such as those that have long been installed in the Mexican-American border, results from the low qualification labor available in the country. However, when the country begins to increase the quality of its labor, if the exchange rate overvalues on account of 
the Dutch disease this workforce will not find employment. And if the country, as was the case with Mexico and the remainder of its manufacturing industry, was already industrialized, but renounced the mechanisms of neutralization of the Dutch disease, the result is that this large group of enterprises will also gradually become "maquiladoras companies". As it usually occurs, the developing country already has the necessary technological conditions to perform more complex activities in its territory, but does not achieve them or fails to achieve them because the Dutch disease is causing an overvaluation of its exchange rate. In this case, the country is limited to low technological content processes. Work processes that require more qualification are reserved to rich countries, on the assumption that developing countries lack this kind of labor, but this is often not true, and high unemployment rates of skilled personnel are observed in those countries.

\section{STAGES}

The Dutch disease exists since the Commercial Revolution and the formation of an international market. Spain's backwardness from the seventeenth century on was certainly caused by the gold it collected from its colonies. Yet, it only was identified in the 1960s, and only lately began to be really discussed. How can we explain, then, that countries that were its victims have been able to industrialize, when economists and politicians were not aware of it? To answer this question we must distinguish the role of the natural resources that give rise to it in two stages. In a first stage, the exploitation of natural resources is a blessing, because it enables the country to take part in international trade, to promote the original capital accumulation, to establish a minimum economic infrastructure, and enables the emergence of a capitalist entrepreneurial class. It is the existence of those resources that makes it possible for a pre-capitalist economy or for an economy with an incipient mercantile capitalism to become a true capitalist economy. It's usually through those resources that the country achieves its insertion in world trade, performs its primitive capital accumulation, and creates an entrepreneurial class. Even in this condition, the country is supposed to tax the Ricardian rents so that these rents do not accrue just to the commodities' producers and to the local consumers (whose wages increase artificially with the overvalued currency) but may be used to develop strategic industries. Yet, as the country develops conditions for industrialization, on the supply side, and, thus, potential conditions for the efficient production of manufactured goods, the Dutch disease becomes a fundamental obstacle. In this second stage, the country faces the challenge of industrializing or, more generally, of developing a broad range of internationally tradable products with increasingly higher value-added per capita, the Ricardian rents derived from goods based on natural resources become the Dutch disease I described above. 
If we abandon this oversimplified concept of two stages, and imagine that, when a country begins to develop, it will be gradually achieving technical competence, we may also reduce the requirement to characterize the Dutch disease. Dutch disease will exist whenever a country has manufacturing sectors with stateof-the-art technology, even though they are not high-tech. On the other hand, we may presume that the more technologically advanced a sector is, the more depreciated will be the exchange rate necessary to make it possible. Once we define Dutch disease according to these terms, and once we accept the assumption above, the transition of a purely commodity-producing economy, using abundant and cheap resources, to a more advanced economy implies the recognition of the Dutch disease and the gradual adoption of mechanisms to neutralize it. It also implies to admit that, instead of two stages, as in Lewis' model (1954), we have several stages that are characterized by the degree of technological sophistication. In all of them the neutralization of the Dutch disease through the imposition of a tax will be necessary; but the method of using the tax resources will be different. In the first stages, the government will use the tax to set up the country's infrastructure and public education system and to create a stabilization fund of taxed commodities - that is, it will try to promote economic development on the supply side and to stabilize the production of the export good. In more advanced stages, when serious problems no longer exist on the supply side and government prefers to reduce the degree of intervention in the economy, as in Norway, it will create an international fund in order to have no additional pressures on the exchange rate.

When the country starts industrializing, economic growth will depend on the neutralization of the disease. This is what happened with all the countries in Latin America and Asia that industrialized in the twentieth century. Latin American countries, for instance, have abundant natural resources, both mineral and agricultural, that allowed them to set up a sector of production and export of primary goods. However, from 1930 on, when this path exhausted its possibilities and the challenge was industrialization, those countries were successful. Between 1930 and 1980, particularly Mexico and Brazil industrialized and grew extraordinarily, because they adopted policies that neutralized the Dutch disease (Palma, 2005). Their politicians and economists ignored the existence of the Dutch disease but made use, in several moments, of multiple exchange rates or complex systems of import duties combined with export subsidies which, basically, addressed the problem by depreciating the currency for the producers of industrial goods. First, they imposed import duties based on the Hamilton-List theory on the infant industry, and considering also the Prebisch-Singer-Furtado theory on the tendency to deterioration of the terms of exchange. Now, the import duty is a partial but effective way of neutralizing the Dutch disease: it merely protects the manufacturing industry against foreign imports, but does not allow it to export; in other words, the import duty neutralizes the Dutch disease for the purposes of the domestic market, not of exports. When the Dutch disease exists, the import duty can only be considered as a manifestation of a country's 
protectionism if the tax rate is higher than the rate necessary to neutralize this market failure; if this is not the case the tariff is just partially correcting a market failure.

Secondly, many countries have used subsidies to exports of manufactured goods. When they had already reached a reasonable degree of industrialization, Brazil and Mexico, for instance, realized that they could compete internationally if they established subsidies to exports of manufactured goods. This way, once again, they were depreciating the effective exchange rate for export purposes, in order to compensate for the appreciation caused by the Dutch disease. When a country levies import taxes on virtually all the goods and establishes subsidies to the export of manufactured goods, it is, in practice, establishing a tax on the commodities that use natural resources and give rise to the Dutch disease. It is a disguised way (actually poorly disguised) of taxing those goods, and, therefore, of neutralizing the Dutch disease, but it is often the only feasible way from a political point of view. In Brazil, for instance, in the 1970s, when there was a major economic growth and a huge increase in exports of manufactured goods, the exchange rate system was roughly as follows: all the goods paid nearly $50 \%$ of import duty, and all the manufactured goods received an export subsidy of nearly $50 \%$, whereas export commodities continued to have the nominal exchange rate appreciated by the Dutch disease. Assuming that this nominal exchange rate, which was also the current equilibrium exchange rate, was 66.66, and that the industrial equilibrium exchange rate was 100, the tax implicit in the system of duties and subsidies that raised the real exchange rate to 100 was $50 \%$.

A duly negotiated and directly established export tax would be more rational, since it would be much easier to manage, given the relatively small number of exported commodities, but a tax faced or seemed to face more political difficulties than the adopted system. It only seemed to face, since this system never fooled anybody: coffee growers were always protesting against the 'exchange rate confiscation'.

\section{DAMAGES?}

So far, I have presumed that specialization in the production of commodities that bring along substantial Ricardian rents is a disease. Yet, according to neoclassical thinking, it is not wrong for a country to specialize exclusively in the exploitation of its natural resources. It is just benefiting from comparative advantages and allocating its resources where they are more profitable. In these terms, industrialization would not be necessary to economic growth. I will not discuss here this argument that already has a long history in economic theory. I merely observe that a developed country such as the Netherlands does not seem to have reasoned like that, because it identified the problem as a disease that was 
killing its manufacturing industry. I also don't believe that this was Norwegians' view when they decided to competently neutralize this disease.

The Dutch disease is an obstacle to economic development on the demand side in so far an overvalued currency precludes investments. When a mediumincome country is threatened by the Dutch disease, it is the demand for the whole local manufacturing industry that is under threat. To presume that the country can incur in premature desindustrialization and fall back to the condition of specialization in natural resource-intensive industries without major costs is not realistic. Secondly, when specialization in natural resources takes place in a country because it is economically unfeasible to implement other economic activities than of non-tradable goods and services, we are in the presence of a disease because, in this situation, the country is limiting its ability to create jobs and giving up the production of any goods with a higher value-added per capita than those existing in the commodities that it produces and exports.

In the first work in which I studied the Dutch disease (Bresser-Pereira, 2007) I argued that the Dutch disease precluded an increase in productivity because it barred the transfer of workforce to sectors with more value-added per capita. This claim, however, wrongly presupposes that the value-added per capita of the good that gives rise to the Dutch disease has a lower technological content than the average of industrial goods. Although the value-added per capita of agricultural and mining production is traditionally lower than that of industrial production and exportable services, this fact is not necessary. There is no reason for agricultural and mining production to be intrinsically less productive or less effective than manufacturing production. Besides, we have been observing in the last 30 years a huge worldwide growth in agricultural productivity, and at the same time mining production becomes more and more sophisticated from the technological point of view. However, even if this exploitation involves a high value-added per capita, the country is renouncing other activities that it is already able to produce with even higher scientific and technological content, and — this is even more serious - is renouncing all the other activities that it would be potentially able to produce with a higher value-added per capita. Besides, there is Dutch disease even if the alternative goods have a value-added per capita nearly identical to the good that causes the Dutch disease but its production is necessary to guarantee the full employment of the available workforce since the goods giving rise to the disease alone are not able to provide this volume of employment. ${ }^{12}$

In a country in which Dutch disease springs mainly from agricultural commodities, their supporters argue that we must also take into account the industrial production generated by those goods. This is undoubtedly true. Given

\footnotetext{
${ }^{12}$ It should be noted, therefore, that I am not taking into account a number of other effects engendered by the dependence on the commodity giving rise to the Dutch disease - such as concentration of political and economic power, increase in economy's vulnerability, etc — as well as distributive issues among the various sectors of society.
} 
transportation costs, producing countries will tend to have an advantage in producing the industrialized good. However, the Dutch disease has an effect on this industrial production as well: although affecting this kind of manufacturing industry with less intensity than the others, it also provokes the regression of the production chain and tends to make profitable only the production of the raw commodity, since it is its marginal cost that determines the exchange rate. In the case of mineral resources it is additionally important to remember that they are exhaustible.

\section{EXTENDED CONCEPT}

The Dutch disease affects not only countries that exploit natural resources. Another source of Dutch disease that is becoming significant is represented by remittances from immigrants; Central American countries are particularly affected by it (Acosta, Lartey and Mandelman, 2007). I will now argue that we may increase the concept of Dutch disease to include as its cause also the existence of cheap labor. If this is true, the Dutch disease becomes an even more general and more serious market failure. Countries such as China or India would also have Dutch disease, and would only develop if they neutralized it by managing their exchange rate. This is exactly what those countries, and, more broadly, the dynamic Asian countries do.

As for the extended Dutch disease, we must take into account the problem of economic growth by transfer of labor from sectors with lower value added to sectors with higher value added. I have said that, in the case of the restricted Dutch disease, this wasn't strictly necessary, since the goods giving rise to the disease are not produced with a necessarily lower scientific and technological intensity than the others. However, in the case of the extended Dutch disease, this problem exists by definition. Goods produced with cheap labor are basically goods that use low-skilled labor, and, therefore, are products with low technological intensity.

The existence of cheap labor does not generate Ricardian rents but has a similar outcome to the effect of cheap natural resource. The necessary condition for cheap labor is a cause of Dutch disease is that the wage spread is substantially larger than in rich countries - a condition that is usually present because in developing countries the difference between the salaries of engineers and wages of blue-collar workers tends to be much large. The industries using mainly cheap labor has a lower marginal cost than the more technologically sophisticated industries. As a consequence, the exchange rate tends to converge on the level that makes it profitable to export goods that use cheap labor. When this happens - and given the fact that the wages of the more skilled workers and managers are desproportionally higher - , the goods using more sophisticated technology and more expensive labor will be economically compromised. Wages paid in more 
sophisticated industries shall be necessarily higher, since they use more skilled labor. If the wage difference between an unskilled worker and an engineer, for instance, were approximately 3 to 4 times, as it is in rich countries, the country would produce, with cheap labor, all kinds of goods with no difficulties but the technical and administrative ones. However, if this wage spread is larger, it is 10 to 12 times, whereas in rich countries it is 3 to 4 times, as it usually occurs, then the extended Dutch disease will exist and will become a serious obstacle to economic growth, because industries with higher technological content shall need a higher exchange rate than the current equilibrium exchange rate determined by the market.

Dutch disease's extended concept is not the only one, but is certainly a fundamental reason why dynamic Asian countries manage their exchange rate so hardly, preventing its appreciation. China, for instance, would never be exporting the increasingly sophisticated goods that it exports without managing its exchange rate. By doing that, it keeps the exchange rate at the necessary level - that is, at the industrial equilibrium exchange rate level - that makes economically viable its sophisticated manufacturing industries.

\section{CONCLUSION}

Dutch disease is the fundamental component of the tendency to exchange rate overvaluation that characterizes developing countries. I believe that the best way to conclude this paper in which I have tried to (a) define it as clearly and precisely as possible, (b) present the concept of extended Dutch disease, which does not result from natural resources but from cheap labor, (c) show that it is a serious market failure, and (d) discuss how it can be neutralized, is to summarize it in a few items. Briefly:

1. Dutch disease occurs when there is a relatively permanent overvaluation of the exchange rate resulting from the country's abundant natural resources (restricted concept) or cheap labor (extended concept), whose low marginal cost is consistent with a market exchange rate substantially more appreciated than the industrial equilibrium exchange rate.

2. there are two equilibrium exchange rates: the current equilibrium exchange rate, that balances intertemporally the country's current account, and is, therefore, the rate the market tends to determine, and the industrial equilibrium exchange rate, that enables industrial sectors using state-of-the-art technology; the Dutch disease occurs when those two equilibriums present conflicting values;

3. the symptoms of Dutch disease in a country are permanent when the country has never produced industrial goods, or they result from some new fact that led the already industrialized country to stop neutralizing 
the disease or, still, from a change in the terms of exchange that increases commodities' market price; in the two latter cases, there will be an appreciation of the exchange rate without a reduction in the country's trade surplus; there will be de-industrialization; and the industrial goodexporting companies will be increasing the imported component in their production in order to gradually transform the country's manufacturing industry into a 'maquila' industry [in-bond industry];

4. the neutralization of the Dutch disease should be made through a tax on domestic sales and on commodity exports that will be different for each commodity, in order to be proportional to the difference between the current equilibrium exchange rate and the industrial equilibrium exchange rate that is necessary for industrial companies using state-ofthe-art technology to be competitive;

5. the more serious the Dutch disease is in a country, the more difficult will be its neutralization, and the lower the probability for this country to industrialize and grow;

6. the resources from the tax created to neutralize the Dutch disease should not be invested in the country (unless they are used in order to stabilize the prices of commodities on which it will be imposed) but invested in an international financial fund so that the inflow of resources does not entail the revaluation of the local currency;

7. despite the fact that the tax should only be imposed on the marginal revenue obtained by the producers resulting from the depreciation assured by the tax, it is not easy to neutralize the Dutch disease in view of the resistance to taxation by exporters of commodities; on the other hand, depreciation finds resistance in the whole population because it causes temporary inflation, and especially because it reduces real wages;

8. although developing countries have always had Dutch disease but did not know, many industrialized; the reason is that, in practice, they have neutralized the Dutch disease through the use of multiple exchange rates, and of import duties and export subsidies that implied a disguised tax on commodities; they justified these policies with the theories of the infant industry and the deterioration of the terms of trade; however, there is no protectionism when duties merely compensate for the appreciation caused by the Dutch disease;

9. Dutch disease is a serious market failure because its non neutralized existence implies negative externalities derived from cheap resources;

10. Dutch disease exists even if the commodities that give rise to it have high technological content, as is currently the case of oil production, and of an increasingly technologically sophisticated agriculture; it is an obstacle to growth because because mining and agricultural activities are not able 
to employ all the labor force, and because it implies that the country renounces its opportunities to invest and to innovate in sectors potentially with still higher technological content and, therefore, with higher valueadded per capita;

11. Dutch disease may also derive simply from cheap labor; in this extended concept of Dutch disease, the condition for it to occur is that the wage spread in the developing country is substantially larger than in rich countries to where the goods would be exported;

12. as for the extended Dutch disease, there is an incompatibility on principle between this non neutralized disease and economic growth, because economic growth always depends on the possibility of transferring labor to sectors with higher value-added per capita - a transfer that is impossible in this case because the more sophisticated manufactured goods necessarily use more skilled labor force (whose salaries are much higher than wages of non skilled workers when compared with rich countries).

the distinction between restricted and extended Dutch disease is theoretical; in practice, both are so integrated that is impossible to distinguish the effects of each one separately; it is impossible, however, to ignore its terrible effects on the economies of developing countries.

\section{REFERENCES}

Acosta, Pablo A., Lartey Emmanuel K. and Mandelman, Federico S. (2007) "Remittances and Dutch disease". Federal Reserve Bank of Atlanta, Working Paper 2007-8, April 2007.

Baland, Jean-Marie and Francois, Patrick (2000) "Rent-seeking and resource booms". Journal of Development Economics, 61: 527-542.

Baldwin, Richard (2006) “The great unbundling(s)". Text for Discussion, Economic Council of Finland, September 2006. Available in www.tinyurl.com/2ol2n8.

Blinder, Alan S. (2006) “Offshoring: the next industrial revolution?”. Foreign Affairs 85(2): 113128.

Bresser-Pereira, Luiz Carlos (org.) (1991) Populismo Econômico. São Paulo: Nobel.

(2002) "Financiamento para o subdesenvolvimento: o Brasil e o segundo consenso de Washington”. In: Castro, Ana Célia (org.), Desenvolvimento em Debate: Painéis do Desenvolvimento Brasileiro Vol. 2. Rio de Janeiro: Mauad/BNDES, 2002: 359-398.

. (2004) "Brazil's quasi-stagnation and the growth cum foreign savings strategy". International Journal of Political Economy 32(4): 76-102.

(2007) Macroeconomia da Estagnação. São Paulo: Editora 34.

Bresser-Pereira, Luiz Carlos and Gala, Paulo (2007) "Por que a poupança externa não promove o crescimento”. Revista de Economia Política 27,1 (105): 3-19. Disponível em: http://www.rep. org.br/

Bresser-Pereira, Luiz Carlos \& Nakano, Yoshiaki (2002) “Economic growth with foreign savings?”. Paper presented at the $7^{\text {th }}$ International Post Keynesian Workshop, Kansas City, Mi., June 28July 3 2002. Available at: http://www.bresserpereira.org.br/ . In Portuguese, at: http://www.rep. org.br/pdf/90-1.pdf . 
Canitrot, Adolfo (1975) “La experiencia populista de distribución de renta”. Desarrollo Económico, 15(59): 331-351. Republished in Bresser-Pereira (org.) (1991).

Chatterji, Monojit and Price, Simon (2008) "Unions, Dutch disease and unemployment". Oxford Economic Papers, 40(2): 302-321.

Cline, William R. and Sidney Weintraub (eds.) (1981) Economic Stabilization in Developing Countries. Washington: The Brookings Institution.

Corden, W. M. (1984) "Booming sector and Dutch disease economics: survey and consolidation". Oxford Economic Papers, 36(3): 359-380.

Corden, W. M. and Neary, J. P. (1982) "Booming sector and de-industrialization in a small open economy". Economic Journal, 92(368): 825-848.

Díaz-Alejandro, Carlos (1981) "Southern Cone stabilization plans". In: Cline and Weintraub (org.) (1981: 119-148). Republished in Bresser-Pereira (org.) (1991).

Dornubsch, Rudy and Edwards, Sebastian (org). (1991) The Macroeconomics of Populism in Latin America. Chicago, Ill.: The University of Chicago Press.

Fajnzylber, P., Loyaza, N., Calderón, C. (2004) "Economic growth in Latin America and Caribbean". Washington: World Bank, Working paper 265, June.

Gala, Paulo (2006) Política Cambial e Macroeconomia do Desenvolvimento. São Paulo: São Paulo School of Economics of Getulio Vargas Foundation, PhD dissertation, May 2006.

Gonzalez, Lauro (2007) Crises Financeiras Recentes: Revisitando as Experiências da América Latina $e$ da Ásia. São Paulo: São Paulo School of Economics of Getulio Vargas Foundation, PhD dissertation, June 2007.

Grossmann, Gene and Rossi-Hanberg, Esteban (2006) “The rise of offshoring: it's not wine for cloth anymore". Text for Discussion, August 2006. Available in www.princeton.edu/ grossman.

Larsen, Erling R. (2004) "Escaping the resource curse and the Dutch disease. When and why Norway caught up with and forged ahead of its neighbors". Statistics Norway, Research Department, Discussion Paper 377, May.

Lewis, Arthur W. (1954) "Economic development with unlimited supply of labor". The Manchester School 22: 139-91.

Ocampo, José Antonio (org.) (2005) Más Allá de las Reformas. Bogotá: Alfa-Omega/CEPAL.

Oomes, Nienke and Kalcheva, Katerina (2007) "Diagnosing Dutch disease: does Russia have the symptoms?”. IMF Working Paper 07/102, April.

Palma, Gabriel (2005) “Cuatro fuentes de 'desindustrialización' en América Latina: Una 'trampa de bajo crecimiento’”. In: José Antonio Ocampo (org.) (2005): 79-130.

Rodrik, Dani (2007) “The real exchange rate and economic growth: theory and evidence". Cambridge, MA: John F. Kennedy School of Government, Harvard University , July. Mimeo

Razin, Ofair and Collins, Susan M. (1997) "Exchange rate misalignment and growth". Cambridge, MA: National Bureau of Economic Research, Working Paper 6147, September.

Sachs, Jeffrey D. (1989) "Social conflict and populist policies in Latin America". In: Brunetta, R. and Dell-Arringa, C. (eds.) (1989) Labor Relations and Economic Performance. London: Macmillan Press. Republished in Bresser-Pereira (org.) (1991).

Sachs, J. D. and A. M. Warner (1999) "The big push, natural resource booms and growth". Journal of Development Economics, 59: 43-76.

. (2001) "The curse of natural resources". European Economic Review, 45: 827-838.

Torvik, R. (2001) "Learning by doing and the Dutch disease". European Economic Review, 45: 285306.

Usui, Norio (1998) "Dutch disease and policy adjustments to the oil boom: a comparative study of Indonesia and Mexico". Resources Policy, 23(4): 151-162. 